\title{
Ethnomiseducationalization: A Legal Challenge
}

\author{
Lance S. Hamilton
}

\section{INTRODUCTION: THE PROBLEM}

My client is a Black American male and the parent of several young Black American sons, one of whom is attending his first year at University X ("Univ. $X$ "), a well-respected institution in the Commonwealth of Pennsylvania. Black Parent ("BLP") has come for advice and legal guidance."

The most prestigious colleges and universities in the country recruited BLP's Black son ("BLS") for both academics and athletics. BLS selected Univ. $\mathrm{X}$ because of its commitment to diversity and its confirmation, in discussions with BLP and BLS, that BLS's expression of his Black viewpoint would not be compromised, constrained, or penalized. Having entered his freshman year at Univ. X, BLS has encountered a different situation. On several occasions, he has been penalized academically for the written expression of his Black perspective. Internal institutional methods of resolution have proven unavailing. Univ. X's faculty and administrators have closed ranks and have supported the denial of this Black point of view.

BLP sees these events as detrimental not only to BLS but also to his other children who may soon face the same chilling experience. Moreover, BLP understands that the injury to BLS undermines his ability to parent as a Black parent and diminishes his capacity to obtain what is in the best interests of his Black child. Furthermore, BLP's inability to provide what is in the best interests of BLS inures to the detriment of his other Black children for whom he, unlike the white counterpart parent, cannot provide continuity of care. ${ }^{2}$

1. The facts of this case are drawn from actual experiences. The Ethnomiseducationalization Ihereinafter Ethnol complaint, or cause of action, discussed infra text accompanying notes 26-36, need not be limited to the fact pattern developed herein, or to the Black father/son relationship. It is equally applicable to the mother/daughter relationship, to cross-gender relationships, or to any parent/child relationship within the Black family.

2. S. Hamilton, Volumes on Black: 1977-present (unpublished manuscripts and tapes on file with author) (Black parent cannot provide continuity of care commensurate with white counterpart because of second-class status of Black Americans; remedial legislation required to effectuate equality). See generally J. COMER \& A. POUSSAINT, BLACK CHILD CARE 1-6 (1975) (racist attitudes and actions: (1) "deny Blacks oneness with society" and security flowing therefrom, (2) "force[ ] Blacks to fight for respect that whites take for granted," and (3) necessarily pose special emotional, social, and psychological problems for Black parents and Black children); J. HALE-BENSON, BLACK CHILDREN: THEIR ROOTS, CULTURE AND LEARNING STYLES 61-64 (1986) (discussing unique parental responsibilities of Black parent); Mosby, Toward a New Specialty of Black Psychology, in BLACK PSYCHOLOGY 33 (R. Jones ed. 1972) (discussing discontinuity in identification process for Black youths as result of white America's cultural devaluation of Black 
BLP and BLS seek legal recourse for their situation.

\section{The FACTS OF THE CASE}

\section{A. Chronicling the Story}

BLS is a young Black American male who excelled academically and athletically throughout his youth. He was the subject of highly competitive solicitation by esteemed academic institutions, such as Princeton, Harvard, and Columbia, as well as by schools renowned for their athletic programs, such as Pennsylvania State University, Florida State University, and UCLA. BLP presented Univ. $\mathrm{X}$ with a young Black American meticulously groomed and honed in all facets of development: academic, athletic, emotional, physiological, spiritual, and cultural. BLP entrusted his Black child to Univ. $X$ with the assurances of its administrators and recruiters that the educational process would not erode the continuity of care provided by BLP and would afford BLS an environment receptive to the exchange of new ideas and differing viewpoints.

When BLS entered the academic arena, he was assigned an adviser ("Adviser A"). Adviser A knew nothing about BLS, his Black family, his Black community, or the concerns of BLS as a Black American male. Adviser A freely admitted his lack of knowledge and conceded that his only concern was BLS's "academic enrichment." This caused both BLS and BLP considerable consternation. BLP insisted that enrichment by the one (academics) could not be achieved without knowledge of the others (BLS, his Black family, his Black community, and the concerns of BLS as a Black American male). BLP subsequently requested that Adviser A be relieved of his duties with respect to BLS. After Adviser A's removal, BLS acted as his own adviser with the aid and guidance of BLP.

On entering the athletic arena, BLS ate at a training table (i.e., meals prepared specially for athletes) which had questionable nutritional value and no cultural meaning for him. ${ }^{3}$ Univ. X's disregard of BLS's dietary needs was more than an insult remediable by an apology. It denied both BLS and BLP the continuity of care afforded to and expected by their white counterparts.

\footnotetext{
Americans).

3. Univ. X's training table completely disregarded the ill effects that a Eurocentric education has upon society - that is, the presupposition that steak, potatoes, spinach, and milk are the order of the day. Mainstream America's cultural dietary habits could have adverse consequences, if left untreated, for the Black community, as well as for the nutritional well-being of BLS. Milk, for instance, is not a nutritional panacea for Blacks. See Scrimshaw \& Murray, The Acceptability of Milk and Milk Products in Populations with a High Prevalence of Lactose Intolerance, 48 AM. J. CLINICAL NUTRTIION 1083, 1097 (1988) ("For adult Africans and Blacks in the United States, percentages of maldigesters range from 65 to 100\%."). BLS's "blue-chip" athletic status resulted from BLP's continuity of care, including nutritional nurturing with blackeyed peas, collard greens, hog maws, pigtail-n-kale, and chitlins. Not only did Univ. X's dietary staff fail to incorporate these items into the university's nutritional scheme, they also frowned upon them.
} 
The emotional and physiological imbalance BLS suffered by Univ. X's failure to address his nutritional needs affected several aspects of BLS's life at the university, not the least of which were his health and athletic proficiency. In addition, the inability of the medical profession to assess the sequelae for BLS concerned and frustrated BLS and BLP.

During BLS's first year at Univ. X, he was required to take an English composition course with Professor C ("Prof. C"). To fulfill one of the written requirements, BLS submitted a paper entitled "PSITOD Process." BLS's paper detailed the distinct and difficult task of raising Black children during slavery days. "PSITOD" ("proud, strong and independent while timid, obsequious and dependent") depicted a rearing process and survival technique unique to the Black slave; it promoted and assimilated seemingly contradictory characteristics in the young Black child. Despite Prof. C's ignorance of this Black childrearing process, as evidenced by her comments, ${ }^{4}$ she deducted points from BLS's evaluation based on content, viewpoint, and history.

In response to her evaluation of the paper, and in accord with university procedure, BLS approached Prof. $\mathrm{C}$ and, when she proved unavailing, Professor B ("Chair"), and eventually Professor A ("Dean"). The professors communicated with BLS and interpreted Prof. C's comments. In every exchange, however, it was apparent to BLS and BLP that each professor lacked respect for and knowledge of the Black perspective, another point of view, and history, and therefore supported her grading and, more importantly, endorsed the rationale of her remarks.

Following are some illustrative examples:

The PSITOD process described the rearing of a Black child during slavery days. Prof. C stated that BLS should have substituted instead the term "early nineteenth century or in the 1800's." These terms are not synonymous. Prof. C's substitution of this euphemism distorted the past and belittled the history of all Black Americans.

Prof. $\mathrm{C}$ also remarked that BLS was "talking about the past" in his description of the PSITOD process, but that he was "not really talking history." Even by mainstream America's definitional standards, tales, stories, and accounts of the past, however transmitted, are history - albeit not the history taught to Prof. C. Her comments demonstrate the presumptuous arrogance of her own miseducation. The idea that she would possess any detailed knowledge of the history of Black Americans is ludicrous since she undoubtedly was taught only the history recorded by mainstream America.

The comments of Chair were equally distressing to BLS and BLP. His analysis asserted that BLS's paper illustrated "how slaves/colonial masters have always interacted" and "the deliberate politics of deception forced onto masters and slaves alike by a fundamentally unjust society." Chair not only rewrote,

4. See infra this Part. 
euphemized, and justified 300 years of slavery in America, he also considered the architects and housekeepers of slavery as victims of their own creation. No slave "interacted" with any slavemaster; there was nothing reciprocal or mutually corresponding in their actions or influence. The use of the term "interacted" belied any claim of knowledge Chair could make. Moreover, there was nothing "alike" forced upon slaves and slavemasters. The slaveowners themselves constructed the "politics" and the "fundamentally unjust system."

To add further insult to injury, Univ. $X$ later had the insensitivity to nominate BLS for a Rhodes Scholarship-a scholarship established by the architect and founder of apartheid in South Africa, Cecil Rhodes. ${ }^{5}$ Univ. X's offer, to a Black nominee, of a scholarship premised upon the belief in white supremacy leads one to question its sensitivity. In addition, Univ. $X$ had the audacity to disagree with and frown upon BLS's decision to decline the nomination in spite of the fact that the offer was an indignity to BLS and BLP. As BLS tried to explain to Univ. $\mathrm{X}$, the Rhodes nomination was anything but an accolade to him, and to accept graciously would be incongruous with who he was and what he, and every American and South African Black, had suffered. He stated that if Hitler's will had provided for scholarships to the University of Berlin and he were a Jewish nominee, no one would question his outrage at and rejection of the alleged accolade.

BLP invested his parental years grooming BLS to a point of excellence while simultaneously instilling dignity and the consciousness of being a Black American male. BLP entrusted his son to Univ. X. Univ. X recruited BLS on the basis of his strengths (intellectual, athletic, etc.), as well as the strength of its proffered diversification. Univ. $X$ has now defalcated and subverted BLP's parenting.

Based on this chronicle, how does one weigh the injuries? As a parent, BLP's damages are irremediable; as a child, BLS's are untold. ${ }^{6}$ Only the

5. Cecil Rhodes, son of an English vicar, became convinced early in his life that the white race was the highest point of evolution in fulfillment of a divine plan, and that his life's goal was to secure the predominance of the Anglo-Saxon people. Rhodes' lifelong endeavor to establish white supremacy over the African continent (from Cape to Cairo) was founded upon and realized through apartheid. Rhodes even tried to assure white supremacy as a consequence of his death. His will established The Rhodes Trust which funds scholarships expressly aimed at educating young scholars and leaders who would appreciate the advantage of imperial unity of English-speaking people. See generally J. MARLOWE, CECL RHODES: THE ANATOMY OF EMPIRE (1972); R. ROTBERG, THE FOUNDER: CECIL RHODES AND THE PURSUIT OF POWER (1988).

6. See, e.g., Mosby, Toward A Theory of the Unique Personality of Blacks-A Psychoculural Assessment, in BLACK PSYCHOLOGY 124 (R. Jones ed. 1972) (formation of Black personality through adverse culturological influences); Poussaint \& Atkinson, Black Youth and Motivation, in BLACK PSYCHOLOGY 113, 113-14 (R. Jones ed. 1972) (shattered self-concept of Black child affects ability to function in society); S. Hamilton, supra note 2 (nature and extent of injuries suffered by Black Americans due to Ethnomiseducationalization has yet to be fully and fairly discussed or considered). The question of remedies commensurate with the damages sustained is a premature one for this Note. Nevertheless, this issue might well include the subjects of affirmative action and reparations. See generally Regents of Univ. of Cal. v. Bakke, 438 U.S. 265, 387-402 (1978) (opinion of Marshall, J.); B. BITTKER, THE CASE FOR BLACK REPARATIONS (1973); Measure to Pay War Detainees Goes to Reagan: Japanese-Americans to Get \$20,000 Each, N.Y. Times, Aug. 5, 1988, at A10, col. 1. 
formulations of Black Psychiatry, Black Sociology, and Black Metaphysics could begin to address reparations for BLP and BLS.?

\section{B. The Limitations of the Legal Status Quo}

Where a right is violated, injury ensues and a remedy is necessitated. ${ }^{8}$ The necessary remedy must be commensurate with the nature of the injury. ${ }^{9}$ Where legal rights that flow directly from the Constitution have been invaded, the federal courts have a duty to fashion a remedy to make good the wrong done, even in the absence of congressional authorization. ${ }^{10}$

In 1857, the highest judicial body of the United States pronounced a National Law of Slavery. ${ }^{11}$ Its Chief Justice justified such an institution because as "beings of an inferior order" for "more than a century" and "altogether unfit to associate with the white race, ... [Black men, women and children] had no rights which the white man was bound to respect .... [Black people] might justly and lawfully be reduced to slavery for [their] benefit."12

Legally reversing that jurisprudence required three constitutional amendments (the Thirteenth, Fourteenth, and Fifteenth Amendments). ${ }^{13}$ Yet these amendments were insufficient to negate the continued second-class status of Black Americans. ${ }^{14}$ Nearly 100 years passed after Chief Justice Taney's infamous decision in Dred Scott $v$. Sandford before the Court conceded-for the sake of global politics-that separate could not be equal. ${ }^{15}$ Anytime legis-

7. S. Hamilton, supra note 2 (properly addressing reparations for Black Americans requires investigation of psychiatry, sociology, and metaphysics from Black perspective).

8. Marbury v. Madison, 5 U.S. (1 Cranch) 137,147 (1803).

9. Milliken v. Bradley, 418 U.S. 717, 738 (1974); Swann v. Board of Educ., 402 U.S. 1, 16 (1971).

10. Bivens v. Six Unknown Named Agents, 403 U.S. 388 (1971) (civil remedy based directly on Fourth Amendment violation by federal agents regardless of state remedy).

11. Dred Scott v. Sandford, 60 U.S. (19 How.) 393, 407 (1857) ("In the opinion of the court, the legislation and histories of the times, and the language used in the Declaration of Independence, show, that neither the class of persons who had been imported as slaves, nor their descendants, whether they had become free or not, were then acknowledged as a part of the people, nor intended to be included in the general words used in that memorable instrument.").

12. Id.

13. See D. BELl, RACE, RACISM AND AMERICAN LAW $\$ 1.10$ (2d ed. 1980); E. FRAZIER, BLACK BOURGEOISIE: THE RISE OF A NEW MIDDLE ClASS IN THE UNITED STATES 20-21 (1957).

14. See Regents of Univ. of Cal. v. Bakke, 438 U.S. 265, 395-96 (1978) (opinion of Marshall, J.) (sociological data offered). See generally OFFICE OF POLICY, PLANNING \& RESEARCH, U.S. DEP'T OF LABOR, THE NEGRO FAMILY: THE CASE FOR NATIONAL ACTION (1965) [hereinafter The Moynihan Report] (discussing lack of equality for Black Americans despite so-called legal equality); REPORT OF THE U.S. NATIONAL ADVISORY COMMISSION ON CIVIL DisORDERS (1968) [hereinafter The Kerner Commission Report] (same); B. WRIGHT, BLACK ROBES, WHITE JUSTICE (1987) (describing double standard in judicial system); Black Progress 'Stagnant' Since '70's, Report Says, JET MAGAZINE, Aug. 14, 1989, at 28 [hereinafter Black Progress] (statement of study commission directed by Yale University economist Dr. Gerald Jaynes: "Many Black Americans remain separated from the mainstream of national life under conditions of great inequality ....").

15. Brown v. Board of Educ., 347 U.S. 483 (1954). See generally D. BELL, supra note 13, $\$ 7.11$, at 437-38 (discussing international pressures, foreign policy and Southern industrial aims as motivation for Court's receptivity to plaintiffs' arguments in Brown); J. GARRATY, QUARRELS THAT HAVE SHAPED THE CONSTITUTION 248 (1962). 
lation is required to effectuate equality, by definition, the subject of the legislation is not on a par with the standard or norm. Moreover, justifying legislation declaring the equality of human beings on the basis of the commerce clause of the Constitution ${ }^{16}$ sends a clear message to Black Americans: each individual's dignity and life are reducible to mere commodities, exchangeable in interstate commerce. ${ }^{17}$

The Black American remains a second-class citizen in the United States. ${ }^{18}$ This is the "stare decisis" facing the Black American and the Black attorney. How can the courts, which helped to create and maintain the Black American's legal suppression, now fashion an appropriate remedy? Would we ask the rapist to describe the nature and extent of the injuries inflicted upon the rape victim? Should the perpetrator determine the appropriate remedy for the victim? Can this logic appease Black America? The true nature of the rights violated for over 300 years can be ascertained, deciphered, and described only by the Black American who has suffered the daily indignities of second-class status. Black Americans must tell the courts what the injury is and how to define the nature of the right. But will the courts, and mainstream America, keep quiet long enough to hear Black Americans detail the nature and extent of the violation and injury?

There is currently no remedy in law for the reality facing the Black American. ${ }^{19}$ The concerns emphasized by the Moynihan Report ${ }^{20}$ and the Kerner Commission Report ${ }^{21}$ are omnipresent. ${ }^{22}$ Can a new legal challenge be envi-

16. Congress enacted the prohibition against racial bias in public facilities, Title $I$ of the Civil Rights Act of 1964, Pub. L. No. 88-352, 78 Stat. 243, pursuant to both the commerce clause and section five of the Fourteenth Amendment. The Court upheld the constitutionality of the Act strictly on the basis of Congress's power to control interstate commerce. See D. BELL, supra note $13, \S 3.6$, at $96-97$.

17. See generally Heart of Atlanta Motel, Inc. v. United States, 379 U.S. 241, 279 (1964) (Douglas, $\mathrm{J}$., concurring) ("My reluctance is not due to any conviction that Congress lacks power to regulate commerce in the interests of human rights. It is rather my belief that the right of people to be free of state action that discriminates against them because of race, . . . 'occupies a more protected position in our constitutional system than does the movement of cattle, fruit, steel and coal across state lines.' . . . [T] he result reached by the Court is for me much more obvious as a protective measure under the Fourteenth Amendment than under the Commerce Clause.") (citation omitted).

18. See sources cited supra note 14 .

19. Had remedies or reparations for racism been attended to in the post-Civil War era by American society, as suggested by Thaddeus Stevens in his plan commonly referred to as "Forty Acres and a Mule" for every freed man, there might have been a different reality facing the Black American today than that chronicled by several authors and judges. See D. BELL, supra note $13, \S 1.11$, at 34 . See generally Regents of Univ. of Cal. v. Bakke, 438 U.S. 265, 395-96 (1978) (opinion of Marshall, J.) (describing the position of Black Americans); E. FRAZIER, supra note 13; B. WRIGHT, supra note 14.

20. The Moynihan Report, supra note 14, at 48 (calling for national action to bring Black Americans to "full and equal sharing in the responsibilities and rewards of citizenship" to enhance "stability and resources of the Negro American Family").

21. The Kerner Commission Report, supra note 14, at 1-29 (stating that segregation and poverty converged on young Blacks to destroy opportunity and enforce failure resulting in crime, drug addiction, welfare dependency, and resentment against society, particularly white society).

22. A relevant study by the National Research Council concurred with the 1968 Kerner Commission's statement:

This is our basic conclusion: Our nation is moving toward two societies, one Black, one White-separate and unequal-What White Americans have never fully understood-but what 
sioned, let alone mustered, to combat the Ethno to which a Black parent and a Black child are subjected? Ethno is false education and perpetual lies regarding primarily Blacks and other minorities. ${ }^{23}$ This Note addresses that legal

the Negro can never forget-is that White society is deeply implicated in the ghetto. White institutions created it, White institutions maintain it, and White society condones it.

Black Progress, supra note 14, at 28-29.

23. S. Hamilton, supra note 2; see also D. Hamilton, How Ethnomiseducationalization Impairs Black Male Student-Athletes at the Collegiate Level (1987) (unpublished manuscript on file with author); L. Rau, Ethno-miseducationalization: An Overview (1977) (unpublished manuscript on file with author). See generally C. WOODSON, THE MISEDUCATION OF THE NEGRO 25 (1990) ("[E]ducation is based primarily upon what [educators] know of the educational needs of the whites.")

Ethno is not confined to a classroom, person, place, or time. Ethno is characteristic of society, nationally as well as internationally. This phenomenon affects practically every aspect of one's life including, but not limited to, education, politics, religion, media, and medicine. Ethno is the act or process of imparting myths and lies so as to create systemically and systematically a foundation of inferiority for Blacks and superiority for whites: the hidden agenda of America.

The myths and lies told over time have recurrent themes and stereotypes which appeal to a people consciously, subconsciously, and unconsciously, and give expression to deep and commonly felt emotions. These myths and lies form the substance of Ethno. Some examples: (1) the myth of the "culturally deprived" and "disadvantaged" child (euphemisms for the Black child) are the linguist's seduction: they imply, through context and use, that the Black child lacks something, making her inferior to the white child-not because of inequities brought about by the subjugation of an entire race of people, but because of some inherent or inherited defect in that group of people; (2) the myth of the "nuclear" family (e.g., "The Cosby Show") is a white family model. Mainstream America's twentieth-century prototype, the so-called nuclear family, consists of husband, wife, son, daughter, and a dog or cat. In this model, the father is the breadwinner, the mother is the primary homemaker and pursues a career not necessarily out of economic need but by choice. This has never been the Black family model, nor could it be. The institution of slavery purposefully and systematically divided fathers and mothers from each other and their children, and disallowed marriage and lineage. The vestiges of that institution are omnipresent. "The Cosby Show" ostensibly is about a Black family, but does not depict the familial relationships which exist in today's Black community or family. It portrays instead the white ideal of what a "successful" family should be; (3) the fashion statement myths are also white (e.g., Gucci, Reebok and Levi's 501 blue jeans). The fashion is geared to white ideals, and these name-brands are developed by white designers as status symbols for white consumers. The advertisements promoting the garments and attire feature men and women in leisurely, carefree lives, relaxing on street corners, strolling in city streets, frolicking in the countryside, and engaging in other activities atypical for Blacks. The advertisements ignore the cultural and societal Black reality: Blacks "strolling" anywhere are subject to question and challenge by law enforcement for "suspicious" behavior. Fashions are designed, styled, and colored for the "class" of white America, not Black America; (4) the myth that Columbus discovered America is false. How could he have "discovered" a land already inhabited and known by Native Americans?; and (5) the myth of equality can be uncovered at the primary school level where we see, for instance, Black children choosing white dolls over Black ones, and white children choosing white dolls over Black ones. Media, sanely applied, could remake the world; the sexual, sensual, successful, sophisticated, and popular image the media projects to all children, however, is a white image, not a Black one.

By this miseducation (formal and via mass media), both child and adult are reared and geared to be racist (overtly and covertly). Most often neither realizes he is racist. The false education and perpetual lies are taught to all children, but the detriment and disadvantage fall upon the Black child and the Black parent.

Ethno is the vital and pervasive societal tool used to maintain the status quo and ensure the survival of mainstream American values, attitudes, and norms. The continuation of Ethno is assured through today's leaders, professors, doctors, and lawyers, who are merely trainees turned trainers. They teach what they have been taught-the Ethno of their respective professions. They ardently resist any challenge to the premises upon which their specialty or expertise is based.

As previously mentioned, Ethno is not confined to one specific area. Instead, it involves a plethora of areas, each of which is influenced by and influences the other. Why is it possible that, in most instances, a professor is able to graduate from an educational institution without being required to learn anything about a culture upon which she now passes judgment? Why are we taught about the Niña, the Pinta, and the Santa Maria, and not about the slave ship Lubeck? Why is there racial gerrymandering? Why does America glorify a city awarded the 1996 Summer Olympics, when in that same city the disappearance and deaths of thirty or more Black children remain unsolved? Why are the most prominent biblical characters depicted as white 
challenge and proposes a model complaint, to be filed in federal court, alleging Ethno as the basis for legal relief for BLP and BLS.

\section{The Solution: Challenging Ethinomiseducationalization}

\section{A. The Ethnomiseducationalization Cause of Action}

Prof. C, like her colleagues and the social and educational institutions that have groomed them, must presume the validity of her incomplete, distorted, and false education, and teach and judge on that basis. As a result of the sociological effects of Ethno, legal rights which proceed from the premise of equality, and to which all persons are entitled regardless of race, are denied to or nullified for the Black American. The Ethno complaint is an attempt to redress this societal disenfranchisement through law.

A cause of action for Ethno encompasses several legal concepts and claims useful in constructing a viable complaint. Ethno includes the impairment of the minds and morals of Black youth by instrumentalities of the state (formal and informal educational institutions). It pervades the educational institutions of America at the primary, secondary, undergraduate, and graduate levels. Ethno also impedes the best interests of the Black child-something distinct from the notion of the best interests of the white, or mainstream, child. ${ }^{24}$ The endorsement of, or acquiescence in, Ethno by American educational institutions weakens the Black parent's ability to parent or maintain continuity of care for his/her Black child. This injures the parent/child relationship and interferes with parental rights and responsibilities which are fundamental, if not sacrosanct, to family. ${ }^{25}$ Child abuse, educational malpractice, and interference with parental rights are necessarily included under the rubric of Ethno.

Ethno, however, is more than the mere accumulation of distinct violations of legal or societal norms. It is the synergistic result, which neither the recognition of individual wrongs nor the enumeration of those separately-defined wrongs is capable of representing or describing. Ethno is that whole which is

persons? Why are the only images of angels white? Why do medicine labels caution only against "redness" or "yellowness" of the skin, a reaction which is premised upon the user's being white? Why are television's portrayals of criminals disproportionately Black?

The answers to these questions, and many more, lie within the phenomenon known as Ethno. The miseducation and lies have so evolved that not only is the status quo maintained, but tragically many Black Americans have been mesmerized by this so-called education and have come to believe in the veracity of the premises set for them by mainstream America, an America which demonstrates little concern for them as human beings striving for first-class citizenship.

24. See sources cited supra note 2.

25. See generally Moore v. City of East Cleveland, 431 U.S. 494 (1977) (Constitution protects sanctity of family and prevents standardization of familial relationships by forcing all to live in narrowly-defined family patterns); Cleveland Bd. of Educ. v. LaFleur, 414 U.S. 632 (1974) (family rights are fundamental); Wisconsin v. Yoder, 406 U.S. 205 (1972) (First and Fourteentl Amendments protect right of Amish parents to shield their children from mainstream thinking of public education to protect moral fiber and religious teaching of children). 
greater-more profound, more pervasive, more injurious, more insidious, more invidious - than the sum of its constituent parts. Ethno is the synthesis of all these wrongs to form a new and different violation which neither society nor the legal system has yet to define fully or discuss and which keeps all Black Americans second-class citizens.

B. The Ethnomiseducationalization Complaint: A Proposed Model ${ }^{26}$

\author{
UNITED STATES \\ DISTRICT COURT \\ MIDDLE DISTRICT OF PENNSYLVANIA
}
BLACK PARENT and BLACK SON, Plaintiffs,

vs.

BOARD OF TRUSTEES of University $X$;

PRESIDENT of University $X$, individually and as President;

PROFESSOR A, individually and as

Dean of Undergraduate Students;

PROFESSOR B, individually and as

Chairperson of the Department of

English; PROFESSOR C, individually

and as Professor/Instructor of

English,

Defendants.

\title{
COMPLAINT FOR DAMAGES, INJUNCTION AND SPECIFIC PERFORMANCE
}

Plaintiffs, Black Parent ("BLP") and his Black Son and student ("BLS"), respectfully allege in this complaint as follows:

26. I chose the Commonwealth of Pennsylvania as the jurisdiction for the facts of the case herein. Legal references are therefore to that jurisdiction. The Ethno complaint, however, can be adapted to the constitution, statutes, and forum of any state or jurisdiction. 


\section{PRELIMinARY STATEMENT}

1. This action is brought by Plaintiffs BLP, the Black father, and BLP's Black son, BLS. Plaintiffs BLP and BLS are residents of Town A, Pennsylvania. As the result of deliberate and knowing acts of Defendants, BLP and BLS were, and continue to be, injured, aggrieved, and afflicted. Defendants' direct, knowing, and deliberate acts, and/or personal involvement, and/or knowledge, and/or acquiescence in the matters and events described in this complaint, have created, and continue to create, injury, threat of injury, and deprivation of and/or interference with constitutional and statutory rights secured to BLP and BLS, by the Constitution and laws of the United States and of the Commonwealth of Pennsylvania including, but not limited to, deprivation of the educational process and Ethnomiseducationalization ("Ethno")-the false education and perpetual lies regarding primarily Blacks and other minorities.

2. BLP and BLS seek damages for past and present injuries suffered from the wrongful acts of Defendants. These acts deprive Plaintiffs of constitutional and statutory rights including, but not limited to, the right to full enjoyment of the educational process. Plaintiffs seek injunctive relief from this Court to protect BLP and BLS from further violations by Defendants of these constitutional and statutory rights. In addition, Plaintiffs seek specific performance of the contractual obligations Defendants owe BLP and BLS. These contractual obligations are described below.

\section{JURISDICTION}

3. Plaintiffs invoke the jurisdiction of this Court under the First, Ninth, Tenth, Thirteenth, and Fourteenth Amendments to the United States Constitution and pursuant to 28 U.S.C. $\S 1651$ and 42 U.S.C. $\S \S 1981,1983,1985$, and 1986. Plaintiffs additionally invoke the pendent jurisdiction of the Court to consider the claims arising under the Constitution and laws of the Commonwealth of Pennsylvania.

\section{PARTIES}

4. Plaintiff BLP is, and at all times relevant to this complaint was, a Black adult citizen of the United States and Pennsylvania, residing in Town A, Pennsylvania. BLP is also the Black parent and legal guardian of Plaintiff BLS, a resident of Town A, Pennsylvania and a citizen of the United States.

5. Defendant University X ("Univ. X") is a nonprofit educational corporation chartered by the Legislature of the Commonwealth of Pennsylvania in $18 x x$. Control of Univ. $X$ is vested in the President of Univ. X ("President") and a Board of Trustees, among whose members ex officio is the Governor of 
Pennsylvania. Univ. $\mathrm{X}$ is not a wholly private institution and is a "state actor" for purposes of this complaint.

6. Upon information and belief, Defendant President is, and at all times relevant to this complaint was, an adult white citizen of the United States and resident of Pennsylvania, employed by Univ. $X$ and acting both as an individual and in the capacity of President of Univ. $X$.

7. Upon information and belief, Defendant Professor A ("Dean") is, and at all times relevant to this complaint was, an adult white citizen of the United States and resident of Pennsylvania, employed by Univ. X as Dean for Undergraduate Students at Univ. X.

8. Upon information and belief, Defendant Professor B ("Chair") is, and at all times relevant to this complaint was, an adult white citizen of the United States and resident of Pennsylvania, employed by Univ. $X$ as Chairperson of the English Department at Univ. X.

9. Upon information and belief, Defendant Professor C ("Prof. C") is, and at all times relevant to this complaint was, an adult white citizen of the United States and resident of Pennsylvania, employed by Univ. X's English Department.

\section{FIRST CAUSE OF ACTION}

(Breach of Contract)

10. BLP's Black son, BLS, graduated from a public high school in Town A, Pennsylvania, in June 19xx. Throughout high school he excelled academically, attained state and national recognition as an athlete in track and field and football, and received community recognition for participation in civic affairs.

11. Over 100 colleges and universities solicited BLS's application to their respective institutions. Univ. X, as well as Harvard, Yale, Cornell, Columbia, Stanford, Princeton, and the United States Military Academy at West Point, was a soliciting school.

12. During this time, representatives from Univ. $X$ visited BLP to confer with him as the parent of BLS. Univ. X solicited BLS as both a scholar and athlete for its institution. Univ. $X$ predicated its solicitation upon its professed commitment to diversification (i.e., exchange of ideas, differing viewpoints, and freedom of expression without fear of injury, reprisal, or penalty). Univ. X's edicts and policies explicitly provided for diversification.

13. Plaintiffs and Univ. $X$ discussed the possibility of BLS's attending the university. Representatives of Univ. X visited BLP and BLS in their home. Futhermore, there were phone conversations and written communications between Plaintiffs and Univ. X. BLP and BLS were invited, and accepted the invitation, to visit the campus and to inquire about the university's policies and educational opportunities. 
14. BLP's primary concern and overriding objective has been, and continues to be, overseeing the care and development of his Black children, and exercising his fundamental parental rights to further the best interests of his Black son, BLS.

15. Univ. X's actions and representations induced BLP and BLS to believe that BLS's interests would best be served by an educational forum committed to the idea of diversification, and the continuity of care which Univ. X claimed it afforded equally to all its students.

16. BLP's reliance upon Univ. X's professed diversification policies led him to determine it was in BLS's best interest to attend Univ. X rather than one of the many other learning institutions that had offered him admission.

17. BLP and Univ. $X$ reached an understanding in the early part of $19 \mathrm{xx}$. BLP agreed that BLS would attend Univ. $X$ beginning in the fall of $19 x x$. In addition, Univ. X, BLP, and BLS signed a Letter of Intent indicating that BLS would participate in the university's athletic program.

18. This understanding created a special relationship between BLP and Defendants vis-a-vis BLS; that is, BLP entrusted part of the care, education, and development (physical, psychological, emotional, and otherwise) of BLS to Univ. X, its agents, representatives, and employees, including the Defendants.

19. During the fall of 19xx, BLS was a student enrolled in Defendant Prof. C's English course. This course was part of the required curriculum for the first year of study at Univ. X. While in attendance, BLS submitted a series of writing assignments to Prof. $\mathrm{C}$ to fulfill the course requirements. These writing assignments were graded on the basis of (a) meeting technical requirements and (b) the content of viewpoints and ideas expressed. The technical requirements were graded according to objective standards. The viewpoints and ideas expressed, however, were graded according to subjective standards. BLS submitted written papers on various topics with a range of subjective views from a Black perspective. Prof. C, Dean, and Chair's comments on BLS's written topics demonstrate that Defendants consistently rejected BLS's work out-ofhand. These comments were based on Defendants' limited and distorted knowledge of BLS and his sociological background. This rejection denied BLP and BLS their right to an educational process that explicitly guaranteed diversity in accordance with Univ. X's policies, and freedom from racial bias.

20. As a professor and employee of Univ. $X$, Prof. $C$ was an agent of Univ. $X$ and duty-bound to uphold the university's policies and edicts, which also formed part of the agreement between Univ. $X$ and Plaintiffs.

21. Relying upon Univ. X's policies and edicts, its educational mandate, and the contractual arrangement embodying the same, BLP encouraged BLS to express freely his viewpoint as a Black American in Prof. C's course, which resulted in Prof. C's penalizing BLS because of his Blackness and in BLS's suffering humiliation from the systematic rejection of his Black viewpoint. 
22. Neither BLS nor BLP understood Prof. C's actions. In overseeing BLS's education, care, and development, BLP advised BLS to seek explanation from Prof. C and from her superiors, Defendants Chair and Dean, in accordance with Univ. X's procedures.

23. Univ. X's process for review of Prof. C's actions was perfunctory at best. Defendants Chair and Dean, acting as Prof. C's superiors, acquiesced in, defended, and/or endorsed the actions of Prof. $C$.

24. To date, BLP and BLS have received no adequate explanation, resolution of, or reparation in this matter.

25. Univ. $X$, through its agents, representatives, and/or employees, breached the contractual arrangement described above in violation of the laws of Pennsylvania. BLP and BLS were injured, and continue to suffer injury, as a consequence of this breach.

\section{SECOND CAUSE OF ACTION \\ (Breach of Oral and/or Written Promises/Representations)}

26. Plaintiffs restate and reallege each and every allegation in II 1-24 of this complaint.

27. Defendant Univ. $X$, through its employees, agents, and/or representatives, has breached oral and/or written promises or representations made to Plaintiffs, on which Plaintiffs reasonably relied to their detriment.

\section{THIRD CAUSE OF ACTION \\ (Educational Malpractice)}

28. Plaintiffs restate and reallege each and every allegation in \\{ 1-24 of this complaint.

29. Defendants have engaged in, and are continuing to engage in, educational malpractice with respect to BLS, in violation of university regulations, edicts, policies, and rules, and of the laws of Pennsylvania and the United States. BLP and BLS continue to suffer injury as a consequence of Defendants' malpractice.

\section{FOURTH CAUSE OF ACTION (Infliction of Emotional Distress)}

30. Plaintiffs restate and reallege each and every allegation in II 1-24 of this complaint.

31. Defendants have intentionally and/or negligently inflicted emotional distress on BLP and BLS in violation of the laws of Pennsylvania. 
32. Defendants knew, or should have known, that their conduct, action, inaction, and/or neglect were likely to cause and did cause BLP and BLS severe mental anguish and emotional distress.

\section{FIFTH CAUSE OF ACTION (Impairment of Parental Rights \& Responsibilities)}

\section{Plaintiffs restate and reallege each and every allegation in II 1-24 of} this complaint.

34. Defendants, by their actions, omissions, endorsement, and/or acquiescence in stifling the expression and development of BLS, have impeded the parental custody and care that BLP is obligated to provide for BLS, and have interfered with the continuity of care BLP sought to provide BLS, thereby jeopardizing the relationship between BLP and BLS on account of their Blackness. Thus Defendants have violated the fundamental parental rights and inherent rights of citizens guaranteed under the Ninth, ${ }^{27}$ Tenth, ${ }^{28}$ Thirteenth, ${ }^{29}$ and Fourteenth ${ }^{30}$ Amendments to the United States Constitution and Article I (sections 1, 3, 25, and 26) of the Pennsylvania Constitution. ${ }^{31}$

27. "The enumeration in the Constitution, of certain rights, shall not be construed to deny or disparage others retained by the people." U.S. CONST. amend. IX.

28. "The powers not delegated to the United States by the Constitution, nor prohibited by it to the States, are reserved to the States respectively, or to the people." U.S. CONST. amend. X.

29. "SECTION 1. Neither slavery nor involuntary servitude, except as a punishment for crime whereof the party shall have been duly convicted, shall exist within the United States, or any place subject to their jurisdiction." U.S. CONST. amend. XIII, \& 1.

30.

All persons born or naturalized in the United States, and subject to the jurisdiction thereof, are citizens of the United States and of the State wherein they reside. No State shall make or enforce any law which shall abridge the privileges or immunities of citizens of the United States; nor shall any State deprive any person of life, liberty, or properiy, without due process of law; nor deny to any person within its jurisdiction the equal protection of the laws.

U.S. CONST. amend. XIV, § 1 .

31.

SECTION 1. INHERENT RIGHTS OF MANKIND

All men are born equally free and independent, and have certain inherent and indefeasible rights, among which are those of enjoying and defending life and liberty, of acquiring, possessing and protecting property and reputation, and of pursuing their own happiness.

SECTION 3. RELIGIOUS FREEDOM

All men have a natural and indefeasible right to worship Almighty God according to the dictates of their own consciences; no man can of right be compelled to attend, erect or support any place of worship, or to maintain any ministry against his consent; no human authority can, in any case whatever, control or interfere with the rights of conscience, and no preference shall ever be given by law to any religious establishments or modes of worship.

SECTION 25. RESERVATION OF POWERS IN PEOPLE

To guard against transgressions of the high powers which we have delegated, we declare that everything in this article is excepted out of the general powers of government and shall forever remain inviolate.

SECTION 26. NO DISCRIMINATION BY COMMONWEALTH AND ITS POLIIICAL SUBDIVISIONS

Neither the Commonwealth nor any political subdivision thereof shall deny to any person the enjoyment of any civil right, nor discriminate against any person in the exercise of any civil right. PA. ConsT. art. I, $\S \S 1,3,5,26$ (1969). 


\section{Sixth Cause of Action \\ (Loss of Parental Enjoyment of Child's Successes \& Services)}

35. Plaintiffs restate and reallege each and every allegation in $₫ \uparrow 1-24$ of this complaint.

36. Defendants, by their actions, inactions, endorsement, and/or acquiescence in impeding BLS's academic expression and development, wrongfully caused BLP's loss of parental enjoyment of BLS's successes and services.

\section{SEVENTH CAUSE OF ACTION \\ (Child \& Parental Abuse/Abuse of Fiduciary Responsibility)}

37. Plaintiffs restate and reallege each and every allegation in $1 \uparrow 1-24$ of this complaint.

38. Defendants have committed abuse and continue to commit abuse upon BLS and BLP, because of their Blackness, in violation of Univ. X's policies, rules, regulations, and edicts, and in violation of the laws of Pennsylvania and of the United States.

\section{EIGHTH CAUSE OF ACtion (Equal Rights Under the Law)}

39. Plaintiffs restate and reallege each and every allegation in TI 1-24 of this complaint.

40. By breaching the aforementioned contractual arrangement, Univ. $X$ denied BLP and BLS, because of their Blackness, the same rights to make and enforce contracts and to the full and equal benefit of all laws and proceedings for the security of persons and property as are enjoyed by white citizens. Plaintiffs are being subjected to different punishment, pains, penalties, and/or exactions than those to which white persons, citizens, and parents would be subjected, in violation of constitutional rights guaranteed Plaintiffs by the Thirteenth and Fourteenth Amendments to the United States Constitution, statutory rights guaranteed pursuant to 42 U.S.C. $\S 1981,{ }^{32}$ and rights guaranteed by Article I of the Pennsylvania Constitution.

32.

All persons within the jurisdiction of the United States shall have the same right in every State and Territory to make and enforce contracts, to sue, be parties, give evidence, and to the full and equal benefit of all laws and proceedings for the security of persons and property as is enjoyed by white citizens, and shall be subject to like punishment, pains, penalties, taxes, licenses, and exactions of every kind, and to no other.

42 U.S.C. § 1981 (1988). 


\section{NinTH CAUSE OF ACTION \\ (Civil Action for Deprivation of Rights: § 1983)}

41. Plaintiffs restate and reallege each and every allegation in $\llbracket \llbracket 1-24$ of this complaint.

42. Defendants' actions and/or omissions, being under color of law, statute, ordinance, regulation, custom, or usage, have deprived BLP and BLS, because of their Blackness, of rights, privileges, or immunities secured to them under the Ninth, Tenth, Thirteenth, and Fourteenth Amendments to the United States Constitution and by 42 U.S.C. $\S 1981$, in violation of 42 U.S.C. $\S 1983 .{ }^{33}$

\section{Tenth Cause of Action \\ (Conspiracy to Deprive of Rights or Privileges: § 1985(3))}

43. Plaintiffs restate and reallege each and every allegation in $\llbracket \uparrow 1-24$ of this complaint.

44. Defendants, by their knowledge, attitudes, personal involvement, actions, and/or acquiescence, have individually, and in concert, wrongfully conspired for the purpose of depriving BLP and BLS, either directly or indirectly, because of their Blackness, of fundamental rights secured to them by the United States Constitution and federal statutes, in violation of statutory rights under 42 U.S.C. $\S 1985(3) .{ }^{34}$ Defendants have unjustly deprived Plaintiffs of, or interfered with, fundamental rights including:

a) BLP's fundamental parental rights and obligations guaranteed under the Ninth, Tenth, Thirteenth, and Fourteenth Amendments of the United States Constitution and Article I of the Pennsylvania Constitution;

b) Plaintiffs' fundamental right to make and enforce contracts with the full and equal benefit of all laws and proceedings for the security of persons and property that is enjoyed by white citizens and parents;

33.

Every person who, under color of any statute, ordinance, regulation, custom, or usage, of any State or Territory ... subjects, or causes to be subjected, any citizen of the United States or other person within the jurisdiction thereof to the deprivation of any rights, privileges, or immunities secured by the Constitution and laws, shall be liable to the party injured in an action at law, suit in equity, or other proper proceeding for redress.

42 U.S.C. § 1983 (1988).

34.

If two or more persons in any State or Territory conspire ... for the purpose of depriving, either directly or indirectly, any person or class of persons of the equal protection of the laws, or of equal privileges and immunities under the laws; ... in any case of conspiracy set forth in this section, if one or more persons engaged therein do, or cause to be done, any act in furtherance of the object of such conspiracy, whereby another is injured in his person or property, or deprived of having and exercising any right or privilege of a citizen of the United States, the party so injured or deprived may have an action for the recovery of damages occasioned by such injury or deprivation, against any one or more of the conspirators.

42 U.S.C. \$ 1985(3) (1988). 
c) Plaintiffs' fundamental right not to be deprived of their civil rights under color of state law, custom, or usage as guaranteed by 42 U.S.C $\S 1983$.

\section{Eleventh CAUSe of Action}

(Negligent Failure to Prevent Interference with Civil Rights: § 1986)

45. Plaintiffs restate and reallege each and every allegation of ๆी 1-24 of this complaint.

46. Defendants knew that wrongs conspired to be done as described in $\{44$ in violation of 42 U.S.C. $\S 1985$ were committed and continued to be committed, had the power to prevent or help prevent the continuation of the same, and neglected or refused to do so. Defendants are therefore liable to BLP and BLS, pursuant to 42 U.S.C. $\$ 1986,{ }^{35}$ for all damages which, by reasonable diligence, they could have prevented or helped prevent.

TWELFTH CAUSE OF ACTION

(Federal \& State Constitutional Violations)

47. Plaintiffs restate and reallege each and every allegation of ๆी 1-24 of this complaint.

48. Defendants, by their respective knowledge, attitudes, personal involvement, actions, and/or acquiescence have, individually and in concert, wrongfully conspired for the purpose of depriving Plaintiffs, either directly or indirectly and because of their Blackness, of fundamental First Amendment rights; of the equal protection and benefit of the laws; of privileges and immunities, and due process secured by the Fourteenth Amendment; of their Thirteenth Amendment rights to be free of the badges and incidents of slavery, including, but not limited to, acts of separation, segregation, and isolation; and of their rights under the Pennsylvania Constitution, including, but not limited to, the right of free communication of thoughts and opinions under Article I, section $7 .{ }^{36} \mathrm{In}$ so conspiring, Defendants have injured Plaintiffs and the relationship between them.

35.

Every person who, having knowledge that any of the wrongs conspired to be done, and mentioned in section 1985 of this title, are about to be committed, and having power to prevent or aid in preventing the commission of the same, neglects or refuses so to do, if such wrongful act be committed, shall be liable to the party injured, or his legal representatives, for all damages caused by such wrongful act, which such person by reasonable diligence could have prevented; and such damages may be recovered in an action on the case; and any number of persons guilty of such wrongful neglect or refusal may be joined as defendants in this action.... 42 U.S.C. \& 1986 (1988).

36. "The free communication of thoughts and opinions is one of the invaluable rights of man, and every citizen may freely speak, write and print on any subject, being responsible for the abuse of that liberty...." PA. ConsT. art. I, § 7. 


\section{THIRTEENTH CAUSE OF ACTION}

(Ethnomiseducationalization)

49. Plaintiffs restate and reallege each and every allegation of 91 1-24 of this complaint.

50. In breaching the aforementioned contractual arrangement, Defendants have engaged in Ethno and continue to engage in same, in violation of the constitutional and statutory laws of the United States and of Pennsylvania. The results of Ethno include, but are not limited to: (a) violating the fiduciary duty created when BLP entrusted BLS to Univ. X's care; (b) impairing the mind and morals of BLS; (c) impairing BLP's fundamental parental rights and responsibilities attendant to the sanctity of family, including but not limited to BLP's right to secure BLS's future and continuity of care, and BLP's obligation to do what is in the best interests of his Black son with the same capacity, force, and effect afforded white parents and their white offspring; (d) inflicting emotional distress upon Plaintiffs; (e) depriving BLS of the educational process; (f) obstructing the best interests of BLS; and (g) depriving Plaintiffs, through commission or omission, of their civil rights guaranteed both explicitly and implicitly by constitutions and statutes, federal and state. Defendants' pattern and practice of Ethno have injured and continue to injure Plaintiffs.

\section{RELIEF REQUESTED}

51. Plaintiffs have sustained and continue to sustain injury as a consequence of Defendants' acts. These injuries include, but are not limited to, severe and intense anxiety, distress, mental anguish, pain and suffering, humiliation, and psychological, sociological, reputational, and physiological dysfunction, and disability.

52. Defendants have engaged in unlawful acts, including a pattern and practice of Ethno. Defendants' acts have deprived and continue to deprive BLP and BLS of their rights secured by the Ninth, Tenth, Thirteenth, and Fourteenth Amendments to the United States Constitution and by 42 U.S.C. $\S \S 1981,1983$, 1985 , and 1986, and by the Constitution and laws of Pennsylvania. Defendants will continue to so deprive Plaintiffs unless restrained by this Court.

WHEREFORE, BLP and BLS respectfully request the following relief:

(a) compensatory damages against Defendants jointly and severally in an amount to be determined;

(b) punitive damages against Defendants jointly and severally in an amount to be determined;

(c) an Order compelling Defendants to comply with their obligations under the aforementioned contractual arrangement; 
(d) an Order enjoining Defendants from engaging in Ethno, and from conspiring for the purpose of ethnomiseducationalizing including, but not limited to, hindering, depriving, or interfering with rights guaranteed by the Constitutions and laws ci the United States and of Pennsylvania;

(e) that this Court retain jurisdiction over this case in the best interests, welfare, health, and safety of BLS, and grant such additional relief as may be required to enforce the orders, remedies, or relief requested; and

(f) award any other relief that it may deem appropriate, including costs, interest, and reasonable attorney's fees pursuant to 42 U.S.C. $\S 1988$.

\section{JURY DEMAND}

A jury trial is hereby demanded as to those issues triable by a jury.

Respectfully submitted,

\section{BLP and BLS}

\section{CONCLUSION: WHY BOTHER?}

Ethnomiseducationalization is ascertainable, recognizable, and demonstrable in reality, but it can only be assessed from the Black perspective. Before we can address what Ethno is, we should discuss why we are addressing Ethno in the first instance.

Black Americans have been unable to invoke successfully the ideals of America. Mainstream America's hypocrisy is that it proclaims independence, autonomy, and the value of daring to be different, but then disagrees with the kind of "different" that some Black Americans dare to be. The Ethno complaint, as a legal challenge, dares to be different. In preparing the Ethno complaint, we have taken what is usable from the law, while simultaneously recognizing that the function of the law will be to make what is usable unusable for the Black plaintiff trying to substantiate a claim for Ethno in the courtroom. ${ }^{37}$

37. Professor Alan Freeman translates the stance of the law into a "plain English" dialogue: THE LAW: "Black Americans, rejoice! Racial discrimination has now become illegal."

BLACK AMERICANS: "Great, we who have no jobs want them. We who have lousy jobs want better ones. We whose kids go to black schools want to choose integrated schools if we think that would be better for our kids, or want enough money to make our own schools work. We want political power roughly proportionate to our population. And many of us want houses in the suburbs."

THE LAW: "You can't have any of those things. You can't assert your claim against society in general, but only against a named discriminator, and you've got to show that you are an individual victim of that discrimination and that you were intentionally discriminated against. And be sure to demonstrate how that discrimination caused your problem, for any remedy must be coextensive with the violation. Be careful your claim does not impinge on some other cherished American value, like local autonomy of the suburbs, or previously distributed vested rights, or selection on the basis of merit. Most important, do not demand any remedy involving racial balance or proportionality; to recognize such claims would be racist." 
In light of this Catch-22 predicament, we must ask ourselves: why bother? Why forge a new legal cause of action, when we know that by that very law we cannot win? This question is of greater significance than how to prepare the Ethno complaint itself.

My answer is: (1) "winning" is not legal victory but societal awakening; and (2) there must be a final attempt at peaceful, legal recourse before other, more drastic alternatives. The goal of the Ethno complaint is not to win by a litigator's standard, but to provoke Black Americans and Black attorneys to organize and to think about creating their own precedents and norms. For the attorney, as well as for the plaintiff, "winning," jurisprudentially, may be surviving a motion to dismiss. In attempting that legal survival comes the societal, as well as the legal, awakening. This societal awakening necessarily embraces the awakening of mainstream America to the knowledge that the enfranchisement of the Black American need not engender the disenfranchisement of the mainstream American.

Ethno, as a legal challenge, might well be the final attempt at peaceful, legal recourse. If we hold firm in our desire to maintain the current legal and social philosophy, then 300-plus years of that philosophy lead us to this conclusion: If not the legal challenge of Ethno-or some similar, sincere attempt to address the wrongs that maintain the second-class status of Black Americans-then it will soon be time to "draw a line in the sand." 38

Freeman, Legitimizing Racial Discrimination Through Antidiscrimination Law: A Critical Review of Supreme Court Doctrine, 62 MINN. L. REV. 1049, 1049-50 (1978).

38. See, e.g., Safire, On Language: War Words, N.Y. Times, Aug. 26, 1990, 6 (Magazine), at 18, col. 3 ("[T]he United States, [President Bush] said, had to 'draw a line in the sand' to defend Saudi Arabia."); The U.S. Stands Up. Who Else?, N.Y. Times, Aug. 9, 1990, at A22, col. 1 ("President Bush has drawn a line in the sand, committing U.S. forces to face down Saddam Hussein."). 